IZA DP No. 8296

Exploring the Causality Links between Energy and Employment in African Countries

Mohamed El Hedi Arouri

Adel Ben Youssef

Hatem M'Henni

Christophe Rault

June 2014 


\title{
Exploring the Causality Links between Energy and Employment in African Countries
}

\author{
Mohamed El Hedi Arouri \\ EDHEC Business School \\ Adel Ben Youssef \\ GREDEG-CNRS and Université de Nice Sophia-Antipolis \\ Hatem M'Henni \\ ESC Tunis, University of Manouba \\ Christophe Rault \\ LEO, Université d'Orléans (UMR CNRS 7322) and IZA
}

Discussion Paper No. 8296

June 2014

IZA

P.O. Box 7240

53072 Bonn

Germany

Phone: +49-228-3894-0

Fax: +49-228-3894-180

E-mail: iza@iza.org

\begin{abstract}
Any opinions expressed here are those of the author(s) and not those of IZA. Research published in this series may include views on policy, but the institute itself takes no institutional policy positions. The IZA research network is committed to the IZA Guiding Principles of Research Integrity.

The Institute for the Study of Labor (IZA) in Bonn is a local and virtual international research center and a place of communication between science, politics and business. IZA is an independent nonprofit organization supported by Deutsche Post Foundation. The center is associated with the University of Bonn and offers a stimulating research environment through its international network, workshops and conferences, data service, project support, research visits and doctoral program. IZA engages in (i) original and internationally competitive research in all fields of labor economics, (ii) development of policy concepts, and (iii) dissemination of research results and concepts to the interested public.
\end{abstract}

IZA Discussion Papers often represent preliminary work and are circulated to encourage discussion. Citation of such a paper should account for its provisional character. A revised version may be available directly from the author. 
IZA Discussion Paper No. 8296

June 2014

\section{ABSTRACT \\ Exploring the Causality Links between Energy and Employment in African Countries}

Using a bootstrap panel analysis that allows for cross-country dependence, without requiring the use of pre-tests for a unit root, we study the causality links between energy use and employment for a sample of 16 African countries over the 1991-2010 period (according to availability of countries' data) in a panel Vector AutoRegressive model. Our results indicate that employment and energy use are strongly linked in Africa. Unidirectional causality from employment to energy use in Tunisia, Cameroun, Zambia and Ethiopia is found. A unidirectional causality from energy use to employment is found in DRC and Egypt. We found also bidirectional causality for Algeria, Benin, Kenya, Mozambique and Tanzania). However, our estimates did not indicate any causality in Big African players like South Africa, Nigeria, Morocco, Ghana and Senegal.

JEL Classification: Q43, Q53, Q56

Keywords: employment, energy consumption, growth, VAR

Corresponding author:

Christophe Rault

LEO, Université d'Orléans

Faculté de Droit, d'Economie et de Gestion

Rue de Blois-B.P. 26739

45067 Orléans Cedex 2

France

E-mail: chrault@hotmail.com 


\section{Introduction}

The effects of energy use on economic variables have been largely discussed in the literature [Barsky and Kilian (2004) and references therein]. Earlier studies have mostly established that energy use is significantly related to economic growth, inflation, terms of trade and stock markets. Paradoxically, the relationship between energy and employment has not been sufficiently studied in the economic literature. High unemployment rates observed in several developed and developing countries in the recent decades have shifted the attention to the variables that may influence the labour market. We contribute to the existing literature by investigating causal relationships between energy use and employment in African countries over the last decades. We are aware that, generally, the energy sector directly employs fewer people than might be expected given its share in the GDP, especially when compared to other industries. In Norway for example, energy-related industries account for $20 \%$ of business sector GDP but just $2.3 \%$ of business sector employment. Nonetheless, recent research in the United States demonstrates that the energy industry supports many more jobs than it generates directly, owing to its long supply chains and spending by employees and suppliers [WEF, 2012].

In the literature, energy-related jobs are generally grouped into three categories: direct jobs, indirect jobs and induced jobs. Direct jobs are jobs related to core activities, such as manufacturing, fabrication, construction, site development, installation, and operation and maintenance. Indirect jobs are jobs connected to the supply and support of energy industry at a secondary level. They can best be thought of as jobs associated with activities such as extraction and processing raw materials, marketing and selling, administration at ministries, work performed by regulatory bodies, consultancy firms, and research organizations. These indirect effects are rarely calculated and mostly estimated via multiplier. Finally, induced jobs are jobs arise from the economic activities of direct and indirect employees, shareholders and governments (e.g. via associated tax revenues). The spending of their earnings can stimulate other industries that themselves are entirely disconnected from the energy sector.

Moreover, it is important to notice that the energy sector's highly skilled workforce is generally well-paid compared to other sectors. As a result of higher wages, energy industry employees contribute more absolute spending per capita to the economy than the average worker and contribute a larger share of GDP per worker than most. The employment multiplier is an important mechanism that quantifies how the energy 
industry (especially oil and gas) influences economic growth and creates jobs. On average, the industry demonstrates an employment multiplier greater than three, meaning that for every direct job created in the oil, natural gas and related industries, three or more indirect and induced jobs are also created across the economy [WEF 2012]. This places oil and gas ahead of many other industries, including the financial, telecommunications, software and non-residential construction sectors in terms of the additional employment associated with each direct worker [WEF 2012].

Thus, we think that is necessary to carry out empirical studies to better understand causal relationships between energy and employment. We believe that Africa constitutes an interesting case to study. Africa renaissance is an increasing subject of interest for both academicians and policymakers. In fact, Africa is exhibiting nowadays an impressive growth rate despite several international crises. Seven out of the 10 fastest growth economies in the world are in Africa and forecasts are waiting for massive growth in Africa in the next decade (Soucat and Ncube, 2014). While Africa is exhibiting these new trends its economy is still facing several challenges and problems among them employment and energy security. For example, while Nigeria is one of the biggest producers of energy in the continent, it faces strong problems in creation of jobs and provision of energy (Andersen and Dalgaard, 2013). Energy provision is fundamental for economic and social development. Securing its energy and extending the energy access to rural populations will strengthen the economic power of Africa and may create jobs. Surprisingly, in the literature, there is no work dealing with relationships between energy and employment in Africa. However, the two issues seem to be strongly linked. From the one hand, energy problems may constraint the economic and human capital development and lower the demographic dividend. ${ }^{1}$ From the other hand, increasing the African population employment would increase the domestic demand especially for energy.

More precisely, three main motivations explain why we should focus on employment and energy in Africa. First, according to the scenario of the Program for Infrastructure Development in Africa (PIDA) Africa will grow on average about 6 per cent per year from 2010 to 2040. This growth implies that the GDP will multiply six fold, and an average per capita income will rise above the USD 10,000 for all countries. Power

\footnotetext{
${ }^{1}$ The demographic dividend is the economic growth potential that is created by favorable shifts in the age distribution of the population (Bloom et al, 2014).
} 
demand is envisaged to increase from 590 TWh in 2010 to more than 3100 Twh in 2040 (Eberhard, 2013). Such huge needs will require massive investment in energy sector and increase in energy use per capita. Consequently an important effect on employment is expected during the next three decades. Second, several African countries have found new discoveries of oil and gas including Kenya, Tanzania, Mozambique, and Angola. East Africa is considered nowadays as a new oil and gas frontier. For example, Angola far from peaking in 2012 could extend its life as a major oil exporter by an additional 30 years and could eclipse Nigeria. These new discoveries are predicting that this industry will be one of the main providers of jobs in the next decades, given the scope of these discoveries. During the last 20 years, figures for known oil reserves in Africa have risen by more than 25 per cent, and gas reserves are now known to be more than 150 per cent higher (Vines, 2013). At the same time, these discoveries imply that the energy use constraint may be relaxed in several African countries during the next decades. Its impact on employment needs to be better understood. Finally, Africa is strongly investing in renewable energies (RE). Those energies are providing higher jobs multiplier than traditional energy sources. Africa has a vast renewable hydropower capacity in Ethiopia, and in the Democratic Republic and Zambia (the water towers of Africa). North Africa countries such Egypt, Libya and Algeria have a large potential for solar energy. The rift valley has a large potential also for clean energy generation. Exploiting these Renewable energies in the future will also be a high source of employment.

This link between employment and energy consumption needs to be better understood in the African context in order to forecast the trends and to better assess economic policies for employment and energy challenges (Rutovitz and Atherton, 2009). While these policies are examined separately in most of African countries, there is a gain to link them and to examine how employment is causing energy use and vice-versa. Our paper fills this gap and offers several contributions to the exiting literature. First, it challenges the lack of studies in matter of energy and employment by considering a large panel of African countries covering all African sub-regions. Second, it studies causal relationships between energy and employment using recent robust panel data econometric methods. Third, it discuss, based on our empirical results, whether it is possible to implement fiscal reforms in order to obtain the double-dividend for the continent (Goulder 1994, Bovemberg, and Goulder 2001, Schneider, 1997 and Smith 
1992). As Africa is growing, the growth-energy nexus is becoming an international matter in order to avoid the same western countries patterns in matter of energy use. Recommending energy and employment policies without understanding the causality between these variables seems to be counter-productive and may harm the economic and environmental assets. While most of previous studies have chosen to work on energy consumption, following Arouri et al. (2014) we will use energy use. We think it is a more relevant variable because it better reflects the situation in African countries characterized by informal consumption of energy (and therefore unaccounted). ${ }^{2}$

The remainder of the paper is organized as follows. Section 2 presents the theoretical background of our study. Section 3 is devoted to the data and the panel Granger causality test methodology. Section 4 reports our findings. Section 5 provides policy discussion and implications. Section 6 offers some concluding remarks.

\section{Theoretical and empirical Background}

This section is dedicated to the discussion of the theoretical and empirical literature linking energy consumption and employment by identifying the main economic arguments before surveying the existing empirical literature.

\subsection{Theoretical links between energy and employment}

Several economic effects are identified when we focus on the link between energy consumption and employment. Six of them need to be highlighted in this short survey: demographic effect, income effect, price effect, substitution effect, technological effect and structural effect.

The first effect is related to demographic change and called the demographic effect. Demographic changes impact directly either energy consumption or employment. As some countries have an increased population provoked by baby-booms, their needs in matter of energy are increasing. While in the short run, only energy needs increase (health care, education services, foods, domestic needs...) and there is no need in matter of employment. The situation becomes more complex when this population enters to the labour market. Employment and energy are growing all together.

\footnotetext{
${ }^{2}$ Energy use refers to use of primary energy before transformation to other end-use fuels, which is equal to indigenous production plus imports and stock changes, minus exports and fuels supplied to ships and aircraft engaged in international transport.
} 
Demography may also impact in-migrating workers and their families (Stenehjem and Metzger, 1976).

The second effect is the income effect. More specifically, when the economy is growing rapidly, the raise of employment will increase the revenues and the domestic demand particularly the energy consumption. This simultaneous growth of energy consumption and employment, which may be at different rates, is defined as the income effect (Murry and Dan, 1992).

The third effect is called the price effect. Exogenous shocks affecting energy sources like oil and gas have a direct and indirect impact on economic growth and on employment. The empirical evidence suggests that oil price changes affect real economic activity and employment (Papapetrou, 2001).

The fourth effect is called the substitution effect. Several authors have shown empirically that energy and labour inputs may be considered as substitutes in the macroeconomic production function. A constraint in the availability of energy may lead to more use of labour and vice-versa. Labour and energy may be considered as imperfect inputs substitutes. A dedicated literature in the nineties has advocated fiscal reforms in order to use more labour and less energy achieving a double dividend (Goulder, 1994; Bovemberg and Goulder, 2001) ${ }^{3}$. The substitution effect and the income effect may move in opposite directions and the net effect may be positive, negative, or neutral, depending on their relative strengths.

Another effect appears in the literature these last years (Laitner, Bernow and DeCicco, 1998; Çetin and Eğrican, 2011) and considers the technological advancements, research and development. The technological effect concerns the replacement of old energies by new energies with new technologies. The new energies have been found to usually enhance employment particularly in the developed countries. Developing countries are two types: those with some capacities to adopt and/or adapt these new technologies which will beneficiate in some ways from these changes; and the lagging countries which will have to import these technologies with a very poor impact on employment.

The sixth and final effect is the structural effect (Jespersen, 1999). Migration from an industrial based economy to a tertiary based economy is usually accompanied by less

\footnotetext{
${ }^{3}$ The double-dividend hypothesis' suggests that increased taxes on polluting activities can provide two kinds of benefits. The first is an improvement in the environment, and the second is an improvement in economic efficiency from the use of environmental tax revenues to reduce other taxes such as income taxes that distort labor supply and saving decisions. (Goulder 1994, Schneider, 1997 and Smith 1992)
} 
pressure on energy use. Then, a switch away from manufacturing toward the service sector is expected to allow a dematerialization of economic activity and an increase in eco-efficiency without increasing unemployment. At the same time, we need to consider in the Africa setting the first stage where some countries have massive migration from agriculture sector to industry sector caused by lack of rains and climate change. This phenomenon is causing urbanization which causes an increase in the energy needs.

Taking all together, these effects may lead to several complex relationships between energy consumption and employment.

\subsection{Empirical findings in the literature}

There are many alternative approaches used for assessment of interactions between energy and employment. We distinguish between the methodologies used and also the level of aggregation. In other words, we have two types of methodologies pre-empting this field of work: the Input/output model and the use of the tests of causality (Granger and others). At the level of aggregation, we can find studies at the macroeconomic, regional or sectoral levels. We also notice in the recent years the emergence of high number of papers dealing with the impact of renewable energies on employment. The results of the empirical investigations available in the exiting literature are rather inconclusive. We start by discussion the relationship for the traditional energy sources before stressing the main findings for the renewable Energies.

\section{(a) Traditional energies and employment}

Akarca and Long (1979) examine the relationship between total employment and total energy consumption using dynamic time series methods. The authors show a unidirectional causality running from energy to employment, without feedback. The long run elasticity of total employment with respect to domestic energy consumption is estimated to be -0.1356 . An increase in total employment should result from a constraint on energy use, rather than the decrease widely predicted.

In contrast, $\mathrm{Yu}$ and Jin (1992) employed cointegration tests to determine whether energy consumption has a long-run equilibrium relationship with the level of income or employment in the USA for the period 1974-1 to 1990-4. They found that the longrun equilibrium relationship fails to exist in either case. The finding implies a longrun neutrality of energy consumption. 
The paper of Yu, Chow and Choi (1988) goes in the same direction. Statistical tests obtained by applying Granger's and Sims' techniques to an extended sample of monthly total employment, non-farm employment and energy data for the U.S.A. for the period from January 1973 to 1984 suggested that there appeared to be a significant negative causal pattern for the non-farm employment and total energy consumption. However, no causal relationship between total employment and energy consumption was detected. The causal relationships between total or non-farm employment and energy consumption were not significant under Granger's test.

These findings were revisited by $\mathrm{Yu}$ and Lee (1995). They indicated the existence of a bi-directional causality between nonfarm employment and energy consumption and between total employment and energy consumption in the U.S.A. Furthermore, their replication of prior studies, after log-transforming, adjusting for seasonality and correcting for unit roots, also produced a unidirectional causal relationship from total employment to energy consumption and a bidirectional causal relationship between nonfarm employment and energy consumption for the 1973:1-1984:6 sample period in the bivariate models. Extending the sample period further, however, completely eliminated the unidirectional causal relationship from total employment to energy consumption in the bivariate system.

Through the use of cross-spectral techniques, Erol (1990) tried to identify the dependence of U.S. industrial energy consumption on the industrial production index and total non-farm employment over business cycles. The author found that the industrial demand for energy is fairly sensitive to business cycles, while the household energy consumption and transportation sector energy consumption were not significantly affected by the expansion and contraction phases of the economy. In addition, he showed that there was a significant degree of correlation between the total non-farm employment and energy consumption over the business cycle frequencies. The evidence indicated a simultaneous response of employment and energy consumption to business cycle movements of the production index and suggested neutrality between energy and labour employment.

Using Hsiao's version of Granger causality and cointegration, Cheng (1998) found that employment (EP), energy consumption (EC), Real GNP (RGNP) and capital were not cointegrated in Japan. EC was found to negatively cause EP whereas EP and RGNP were found to directly cause EC. It was also found that capital negatively Granger-causes EP while RGNP and EP were found to strongly influence EC: The 
findings of this study suggested that a policy of energy conservation may not be detrimental to a country such as Japan. In addition, the finding that energy and capital are substitutes implied that energy conservation would promote capital formation, given output constant.

In Jeeninga et al. (1999), the relationship between investments in energy efficiency and employment was investigated-by means of a dedicated input/output simulation approach. The employment effects of energy conservation schemes were determined for France, Germany, the Netherlands, Spain and the United Kingdom. The main finding of this study was that investment in energy efficiency in the residential sector had a positive effect on total employment. However, the employment effects of the programmes were generally small compared to the size of the investment.

Shi, Heerink and Qu (2009) examined the impact of off-farm employment on rural household energy consumption choices. To this end, a hybrid farm household/village computable general equilibrium (CGE) model was used that has been calibrated for a remote village in Northeast Jiangxi Province where fuel wood was the main source of energy. They found that fuel wood was not an inferior good. The positive impact of more food consumption on fuel wood collection more than compensated the higher leisure demand associated with higher incomes. Shifts in production activities and in prices on village factor markets caused by increased labour scarcity (the lost-labour effect of off-farm employment), on the other hand, caused a reduction in fuel wood collection and consumption. For local off-farm employment the income effect dominated the lost-labour effect, resulting in a positive overall impact of higher offfarm participation on fuel wood consumption.

More recently, Chang, Fang and Wen (2001) use cointegration analysis and vector autoregressive models (VAR) to examine the causal relationships among energy consumption, employment, and output for Taiwan. Cointegration test result has indicated that these three variables are cointegrated with one cointegrating vector. The results from Granger causality tests based on vector error-correction models (VECM) suggested bidirectional Grange causality for employment-output and employmentenergy consumption, but only unidirectional causality running from energy consumption to output.

In the same vein, Narayan (2005) studies the relationship between electricity consumption, employment and real income in Australia within a cointegration and causality framework. The author found that electricity consumption, employment and 
real income are cointegrated and that in the long-run employment and real income Granger cause electricity consumption, while in the short run there is weak unidirectional Granger causality running from income to electricity consumption and from income to employment.

The study of Ghosh (2009) probes nexus between electricity supply, employment and real GDP for India within a multivariate framework using autoregressive distributed lag (ARDL) bounds testing approach of cointegration. Long-run equilibrium relationship has been established among these variables for the time span 1970-71 to 2005-06. The study further established long- and short-run Granger causality running from real GDP and electricity supply to employment without any feedback effect. Thus, growth in real GDP and electricity supply were responsible for the high level of employment in India.

Payne (2009) founds with the Toda-Yamamoto long-run causality test a positive and statistically significant causality from energy consumption to employment in Illiois (USA) over the period 1976 to 2006.

\section{(b) Renewable Energies and Employment: Green Jobs}

Most of the economic literature has examined the relation between energy and output variables with special focus on GDP and growth as proxies of output lagging behind employment. One key explanation is the fact that employment is close to GDP. A new literature is focusing nowadays on renewable energies (RE) and its outputs. They are mainly considering the employment as the main output. The main explanation relies to the double dividend hypothesis. Promotion of green growth can help achieving better environmental and employment results. "Conventional energy technologies such as nuclear energy, hydropower and natural gas or coal based power generation have also been subjected to job creation assessments. Studies that focus on renewable technology, however, make up the majority of the available literature, as only few studies consider fossil-based alternatives." (van der Zwaan et al. 2013, p:298). The second explanation relies to the fact that RE are less capital intensive and are more labor intensive than traditional sources of energy. Such characteristic implies more jobs. 
In fact, since a decade an emergent literature is showing the importance of RE in matter of jobs creation especially in the context of the European Community (EC). ${ }^{4}$ EC is trying to make its energy transition and to move to more renewable energy sources (RES) such as solar energy (photovoltaic and thermal), wind energy (on and off-shore), biomass based energy, and geothermal power in order to mitigate climate change and reduce its air pollution. One of the arguments is the fact that this transition may provide new jobs and will have an impact on the labor market. RES can stimulate a broad range of sectors directly or indirectly related to energy use and production ${ }^{5}$. It is fully accepted nowadays that increase in renewable power leads to job creation. The RE labor intensity is higher than the conventional energy sources (Llera et al, 2013). For every MW installed it is estimated that renewable energy sources generate between 1.7 and 14.7 times more jobs than natural gas generation plants (Heavner and Churchill, 2002) and up to 4 times more jobs than those supplied with coal (Singh and Fehrs, 2001).

Several papers and reports have tried then to calculate those employment gains. Since the European Union has committed first itself to reach 20 percent of the share of total energy from renewable energies in $2020^{6}$ several papers have tried to calculate the expected employment effects of such policy. The European Commission calculation reports positive employment net effect of advanced RES deployment in Europe (ISI, 2009). Blazejczack et al. (2011) found a positive impact of RES deployment in Germany. Lehr et al. (2012) evaluated that the net impact of RE expansion in the German Market, taken into account several assumptions about international trade, fuel prices, and domestic installations. Their results show positive net effect on the labor market. RE expansion will reach around 150 thousands in 2030. Gross employment will increase from 340000 in 2009 to between 500000 and 600000 in 2030. Tourkolias and Misrasgedis (2011) found positive employment effects of an increase

\footnotetext{
${ }^{4}$ Cameron and van der Zwaan (2012) listed at least 60 papers focusing on the relation between RES and employment.

${ }^{5}$ Lambert and Pereira (2012) have presented a discussion of the various factors that influence the analysis of renewable energy and its impact on employment. A critical evaluation of the literature revealed factors that should be considered when completing a study about renewable energy and employment: labor intensity of renewables; cost increases and availability of investments; counting job losses; job quality and skills, model assumptions and sources of information. Analytical studies using extensive surveys were found to be more appropriate for regional studies while input-output methods were better suited to national and international studies.

${ }^{6}$ The renewable energy directive 2009 - European Commission.
} 
in the share of RES in the Greek economy. Greece has a national target to reach $40 \%$ of its energy from RES while nowadays its share is only 12\%. Llera et al. (2013) found similar results by examining the reinforcing effects of the expansion of the renewable technologies industry in Spain. Herrero et al. (2011) found that the net impacts of a transition to renewable energies in Hungary is positive in the entire scenario they use it.

Similar results are found for the USA. Wei, Patadia and Kammen (2010) found that all non-fossil fuel technologies (renewable energy, EE, low carbon) created more jobs per unit energy than coal and natural gas in the U.S.A. Aggressive measures could generate over 4 million full-time-equivalent job-years by 2030 while increasing nuclear power to $25 \%$ of overall generation in 2030 could yield an additional 500,000 job-years. Several papers ${ }^{7}$ however doubt positive employment impacts and advocate that such calculation are subject to other policy considerations such the promotion of the feed-in tariff in Germany.

A wide range of papers are investigating nowadays these findings in the context of emerging countries in order to discuss the general validity of this purpose. van der Zwaan et al. (2013) estimate the required jobs for the wind and solar energy sector for the MENA region in 2050. They made this estimation under the assumption that at that time $60 \%$ of energy will be provided by RE. RE jobs required will be 155,000 direct jobs and 115,000 indirect jobs. They also suppose that this simulation takes into account that some component of solar and wind energy will be manufactures in the region itself. Cetin and Egrican (2011) find positive job impacts of solar energy in Turkey. Simas and Paca (2014) report positive employment impacts of RE in Brazil. The job potential corresponds to 13.5 persons-year equivalents for each MW installed between manufacture and first year operation of a wind power plant, and 24.5 persons-year equivalents over the wind farm lifetime. Results show that major contributions from wind power for job creation are in the construction stage.

\footnotetext{
${ }^{7}$ Frondel and al. (2009) doubt positive employment impacts of RES increase driven by the German feed-in-tariff in the long run. Previously, Hillebrand et al. (2006) concluded that RES promotion will have positive net employment impacts in the short run due to RES installations, which will turn negative in the long run due to the long-term costs of the feed-in tariff, which guarantees fixed tariffs for 20 years. Similar findings are provided by Böhringer et al. (2013). According to them, their computable general equilibrium analysis suggests that the prospects for employment and welfare gains are quite limited and relies on the subsidy rate practiced by the German authorities.
} 
Lambert and Pereira (2012) have presented a discussion of the various factors that influence the analysis of renewable energy and its impact on employment. A critical evaluation of the literature revealed factors that should be considered when completing a study about renewable energy and employment: labour intensity of renewables; cost increases and availability of investments; counting job losses; job quality and skills, model assumptions and sources of information. Analytical studies using extensive surveys were found to be more appropriate for regional studies while input-output methods were better suited to national and international studies.

To our knowledge the only study for an African country was conducted by Openshaw (2010). The study undertaken in Malawi from 1995 to 1997 and 2007 to 2008 estimates the supply and demand of household energy. Openshaw (2010) indicated that biomass has been not only the principal energy, accounting for 89 percent of demand, but also the main traded energy in the two time periods accounting for 56-59 percent of commercial demand. Petroleum products supplied 26-27 percent, electricity 8-12 percent and coal 6-10 percent. The market value of traded wood fuel was US\$ 48.8 million and US\$ 81.0 million in 1996 and 2008 respectively, about 3.5 percent of gross domestic product (GDP). The study found that in 1996 and 2008 respectively, the equivalent of 93,500 and 133,000 full-time people was employed in the biomass supply chain, approximately 2 percent of the potential workforce. In contrast, about 3400 and 4600 people were employed in the supply chain of other fuels in these years. If the Malawi findings were applied to the current estimated wood energy consumption in sub-Saharan Africa, then approximately 13 million people could be employed in commercial biomass energy; this highlights its importance as a means to assist with sustainable development and poverty alleviation.

This rapid literature review shows contradictory results. The Energy-Employment nexus needs further empirical investigation especially in the African context. This is especially needed given the urgency of Africa to challenge the unmet needs for energy in the next years.

\section{The African context}

Africa is nowadays one of the most growing regions in the world. In the last ten years and despite the world crises touching all the most developed countries, African growth remains positive and even increased to nearly 6\% in 2006 and 2007 (figure 1). 
And the year after in the heart of the economic torments, Africa was performing 3\% far from the negative figures of the majority of the developed countries in the world.

Figure 1: Evolution of the GDP growth in Africa for the period 1991-2011

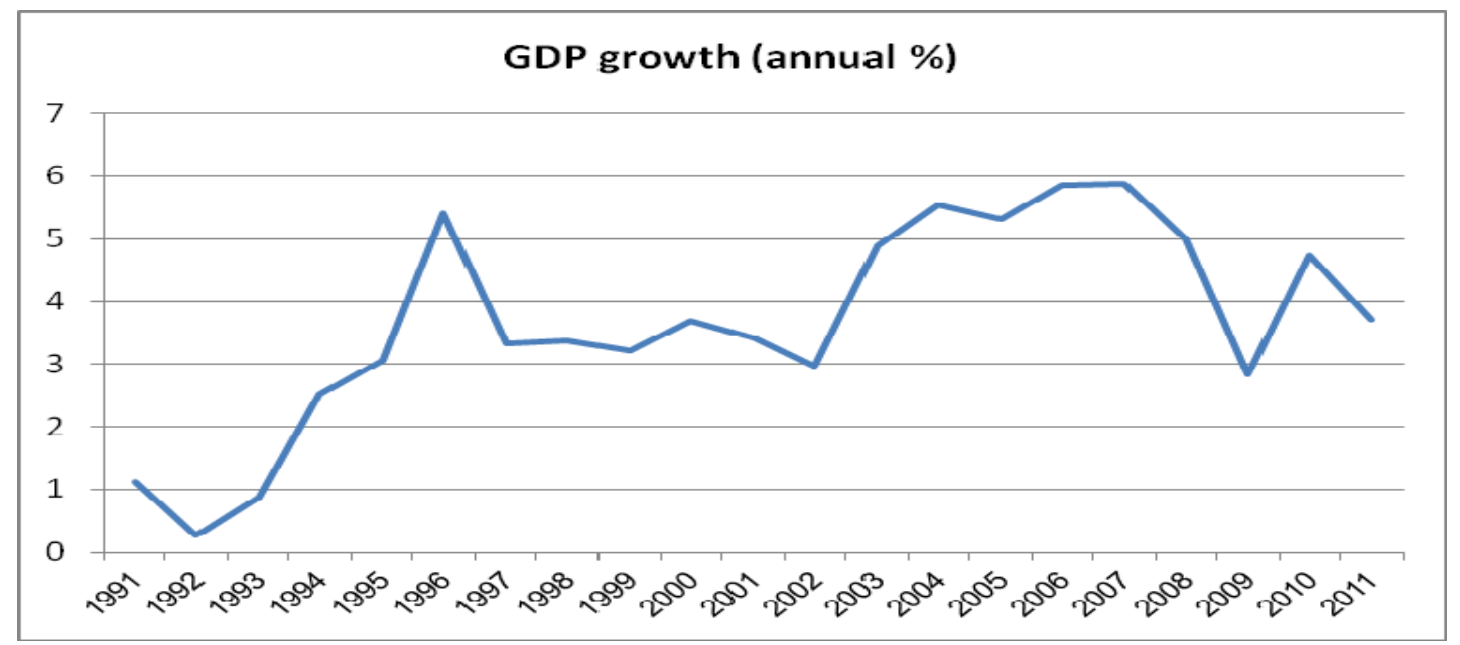

These relatively high levels of growth could not be achieved without an increased demand on the energy sector. And effectively, the use of energy in Africa continued to grow from one year to another during the past 40 years and particularly since 1991 (figure 2). On average the total amount of energy used in Africa has more than tripled during the past forty years. It should be noted also that some stability is achieved in the end of the period. It will be necessary to check the figures of 2012 and 2013, which will be published soon, to see if these figures are cyclical or if they represent a new trend for the use of energy. Obviously the final trend of the total use of energy is also related directly to the demographic growth of the African population which is among the highest in the world.

Figure 2: Evolution of energy use in Africa between 1971- 2011

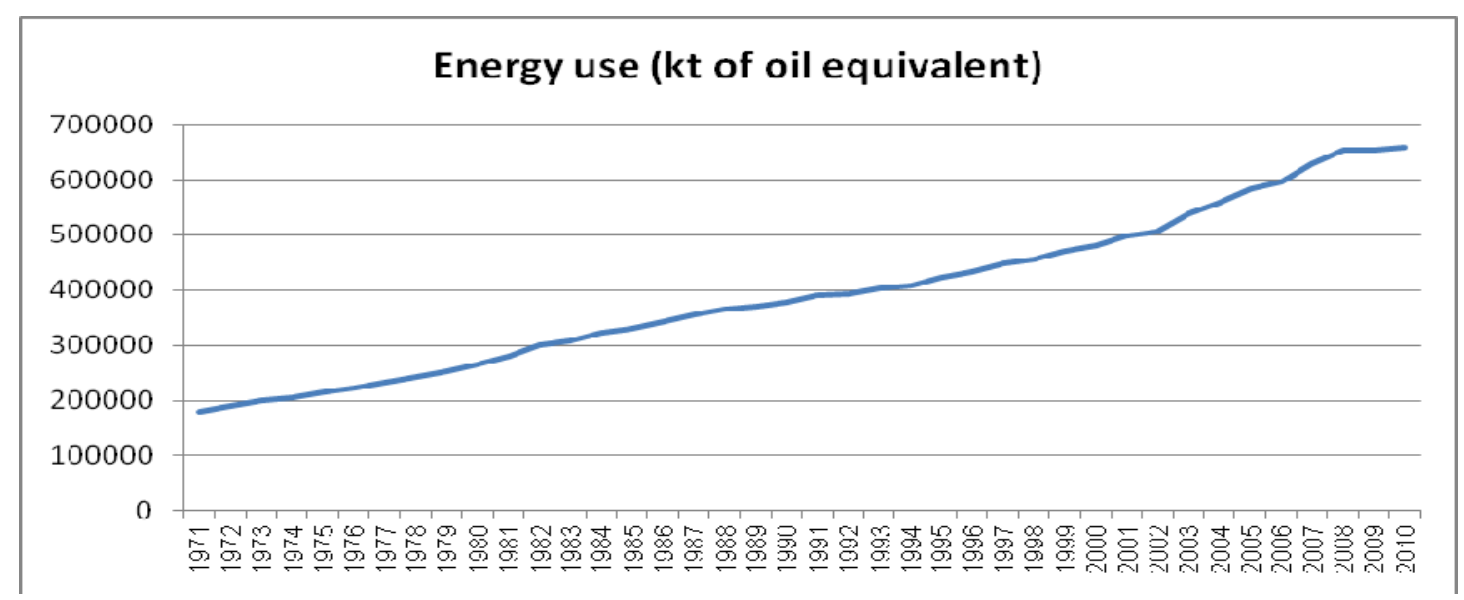


Once the total amount of energy is deflated by the number of inhabitants, the curve becomes flatter (Figure 3) and the growth rate of the energy use per capita becomes lower although still positive. This means that the population growth has had the effect of slowing the growth of the amount of energy use per capita.

Figure 3: Evolution of energy use per capita in Africa between 1971- 2011

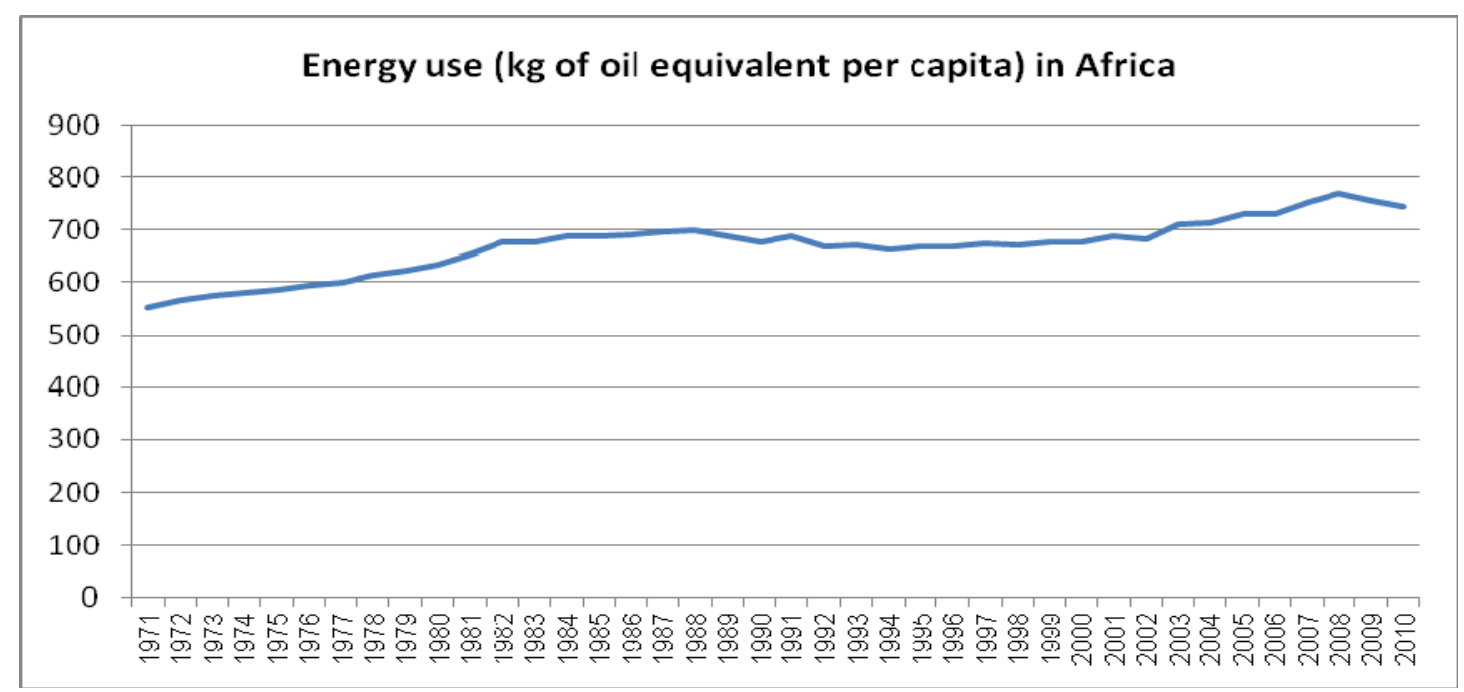

The employment rate of the population over 15 years of age has remained fairly stable (between $58.5 \%$ and $60.5 \%$ ) during the last 20 years. In summary, we can divide the period 1991-2011 into three parts. The first from 1991 to 2001 characterized by a stagnation rate between $58.5 \%$ and 59\%. The second period, from 2002 to 2008 , saw the curve passing to a clearly positive slope and going over $60 \%$. Then a period of stability or even decline reappears from 2009 until 2011. The latter period is synonym of first signs of unemployment climbing.

It is obvious that the growth achieved in Africa in recent years was not followed by an improvement of the situation of job seekers. Decision makers therefore have to develop strategies (policies) which must improve both the overall economic situation and also employment. In this paper, we argue that the energy sector can play this role. 
Figure 4: Employment to population ratio +15 for the period 1991- 2011

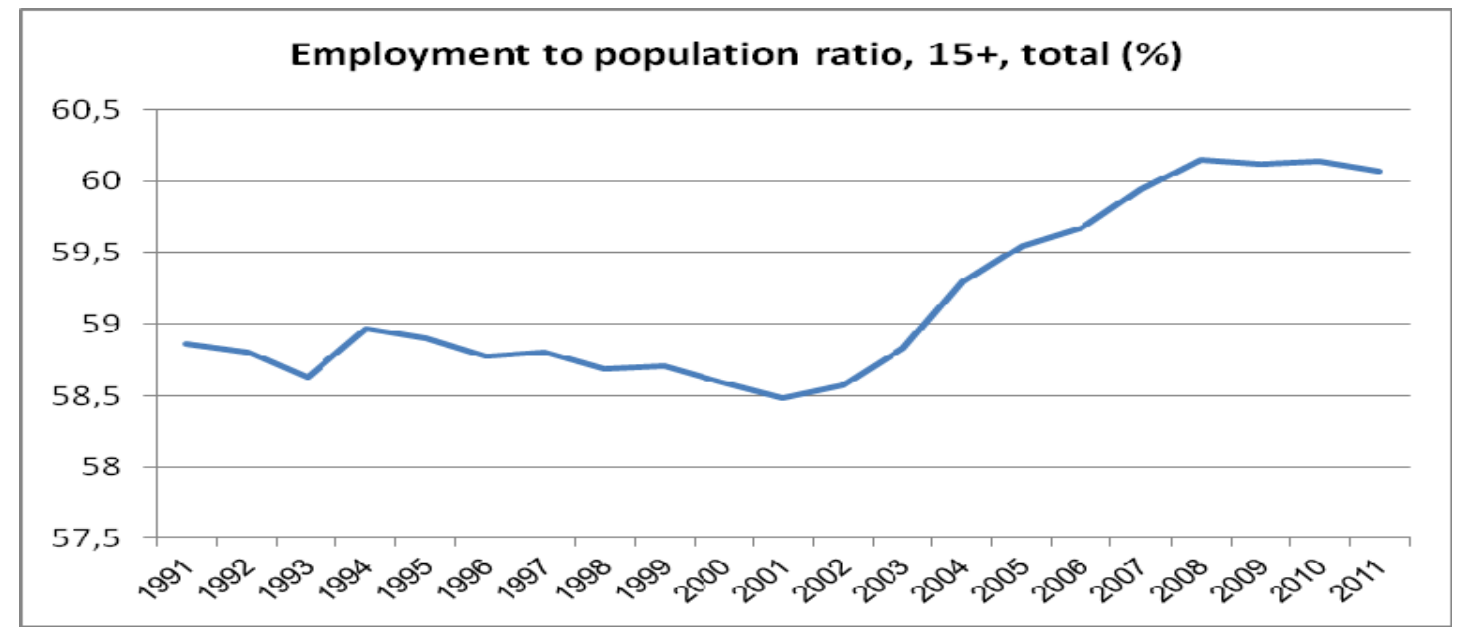

The superposition of the two previous graphs suggests the possibility of a correlation between the two variables (figure 5). ${ }^{8}$ Indeed, the two indicators of energy and employment seem to have the same evolution in time. But this kind of graph does not give us an exact idea about the level of this correlation, nor informs us about the type of relationship, nor on the direction of causality. It is also a global relationship that hides all conceivable developments that characterize each African country. But this requires more investigations and need more sophisticated econometric techniques that will be put in place in the next section.

Figure 5: Comparison between the evolution of the rate of employment and the energy use per capita

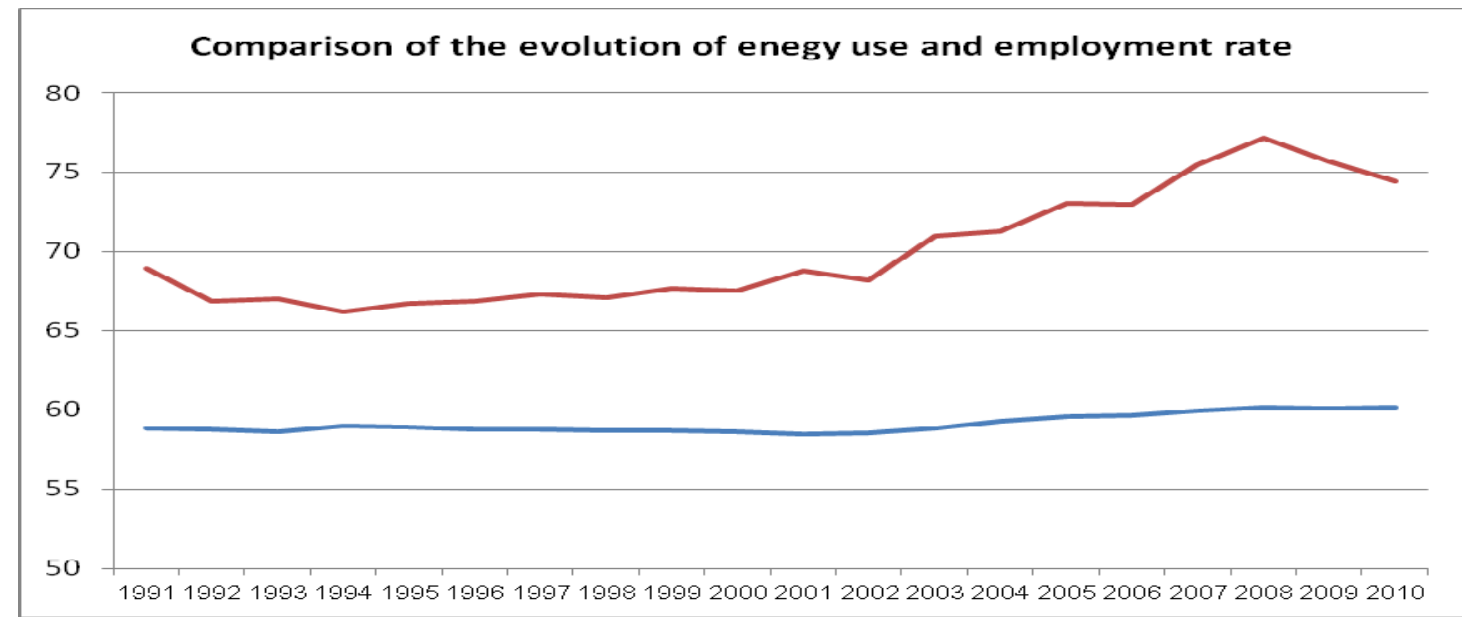

\footnotetext{
${ }^{8}$ To have a comparable evolution of employment and energy use in the same graphic, we divided the per capita energy use figures by ten.
} 


\section{Data and Methodology}

This paper contributes to the literature with a bootstrap panel analysis of causality relationships between energy use and employment for a sample of 16 African countries: Algeria, Benin, Cameroon, Democratic Republic of Congo (DRC), Egypt, Ethiopia, Ghana, Kenya, Morocco, Mozambique, Nigeria, Senegal, South Africa, Tanzania, Tunisia and Zambia. We consider here annual data for energy use ${ }^{9}$ and employment ${ }^{10}$ (as well as a series of control variables associated with both energy use and employment: economic growth, inflation and exchange terms) over the 19912010 period extracted from World Development Indicators Database (World Bank, 2013). ${ }^{11}$ From an econometric point of view, we first estimate a panel Vector AutoRegressive (VAR) model and then implement the panel-data approach of Kónya (2006), based on Seemingly Unrelated Regressions (SUR) system and Wald tests with country specific bootstrap critical values. In this specific framework we allow for cross-country correlation, without the need of pretesting for unit roots and cointegration (as in Phillips, 1995).

Specifically, we consider the following bivariate finite-order vector autoregressive (VAR) model to energy use (E) and employment (EMPLOY): ${ }^{12}$

$$
\left\{\begin{array}{l}
E_{i t}=\alpha_{1 i}+\sum_{j=1}^{p_{1 i}} \beta_{1, i, j} E_{i t-j}+\sum_{j=1}^{p_{2, i}} \gamma_{1, i, j} \operatorname{EMPLOY}_{i t-j}+\varepsilon_{1, i, t} \quad t=1, \ldots, T i=1, \ldots, N \quad \text { (1a) } \\
\text { EMPLOY }_{i t}=\alpha_{1 i}+\sum_{j=1}^{p_{1 i}} \beta_{2, i, j} E_{i t-j}+\sum_{j=1}^{p_{2, i}} \gamma_{2, i, j} \text { EMPLOY }_{i t-j}+\varepsilon_{2, i, t} \quad t=1, \ldots, T i=1, \ldots, N
\end{array}\right.
$$

, where $i(i=1, \ldots, N)$ and $t(t=1, \ldots, T)$ denote respectively the country, and the period, whereas $j$ indicate the lag, and $p_{1 i}, p_{2 i}$ and $p_{3 i}$, represents the maximum lags in equations (1a) and (1b). $\varepsilon_{1, i, t}$ and $\varepsilon_{2, i, t}$, are assumed to be white-noises and can be correlated with each other for a specific country, but not across countries.

\footnotetext{
${ }^{9}$ Energy use refers to use of primary energy before transformation to other end-use fuels, which is equal to indigenous production plus imports and stock changes, minus exports and fuels supplied to ships and aircraft engaged in international transport. International Energy Agency (IEA Statistics (C) OECD/IEA, http://www.iea.org/stats/index.asp).

${ }^{10}$ Employment to population ratio is the proportion of a country's population that is employed. Ages 15 and older are generally considered the working-age population. International Labour Organization, Key Indicators of the Labour Market database.

${ }^{11}$ Data are available at http://data.worldbank.org/.

${ }^{12}$ We would like to thanks L. Kónya for sharing his original TSP program with us, which we have then modified for our investigation. For concision purpose, we do not show control variables in the presentation of models and results.
} 
Then, the above VAR is estimated using Zellner's Seemingly Unrelated Regressions (SUR), because potential interactions may affect individual regressions through contemporaneous correlation ${ }^{13}$ within equations (1a) and (1b). Finally, Granger causality is investigated with Wald tests with critical values generated for each country by simulation and bootstrapping techniques.

In equations (1a) and (1b) of the VAR, in country $i$ there is one-way Grangercausality from EMPLOY to $\mathrm{E}$ if in the first equation not all $\gamma_{1, i}$ are zero but in the second all $\beta_{2, i}$ are zero; there is one-way Granger-causality from E to EMPLOY if in the first equation all $\gamma_{1, i}$ are zero but in the second not all $\beta_{2, i}$ are zero; there is twoway Granger-causality between E to EMPLOY if neither all $\beta_{2, i}$ nor all $\gamma_{1, i}$ are zero; and there is no Granger-causality between E to EMPLOY if all $\beta_{2, i}$ and $\gamma_{1, i}$ are zero. ${ }^{14}$

This procedure has at least three advantages. Firstly, it does not assume that the panel of countries is homogenous, so it is possible to test for Granger-causality on each individual country separately. Secondly, this panel methodology which is an extension of the approach proposed by Phillips (1995) for testing for Granger noncausality on time series data in VAR models expressed in levels, does not also necessitate the use of pre-tests for a unit root or cointegration. However, it still necessitates determining the model's optimal lag length which can easily be done using the Akaike (AIC) or Schwarz Information Criterion (SIC). This is a very nice property since it is now well known that unit-root and cointegration tests have low power in finite samples, and different tests may lead to opposite conclusion. Thirdly, this panel Granger causality approach enables the applied economist to know for how many countries and for which countries of the panel there exists one-way, two-way, or no Granger-causality.

\section{Results}

The implementation of the AIC and SIC criteria in a model initially incorporating a maximum lag length of 3 leads to the selection of a VAR(1) model in accordance with data properties. Besides, misspecification tests report in this case no deviation from

\footnotetext{
${ }^{13}$ Since there exists very strong economic links between countries of Africa, this assumption seems to be very relevant here.

${ }^{14}$ It has been pointed out by Kónya (2006) that this definition was associated to one-period-ahead Granger causality.
} 
usual underlying assumptions. We then use the Breusch-Pagan Lagrange multiplier statistic (1980) to test for the diagonal error variance-covariance matrix. We report that within the different systems considered, the no contemporaneous correlation null hypothesis is always rejected at the five percent level of significance. This provides clear evidence in favour of the use of SUR estimators which lead to more efficient parameter estimates than Ordinary Least Squares.

Tables 1a and $1 \mathrm{~b}$ summarize our results. ${ }^{15}$ A unidirectional causality from employment to energy is found for (Cameroon, Ethiopia, Tunisia, Zambia), while a unidirectional causality running from energy to employment is obtained for (Democratic Republic of Congo, Egypt). One can also notice bidirectional causality for (Algeria, Benin, Kenya, Mozambique, Tanzania).

The first group of countries exhibit a unidirectional causality from employment to energy. The main explanation is linked to the productive and revenue effects. The revenue effect means that once an individual finds a job, the revenue generated leads to an expansion of energy consumption. The expansion of economic sectors leads to a growth and an investment that cause an employment effect. In fact, the private sector hires more employees. This phenomenon causes an expansion of its energy use. As an illustration, Tunisia has exhibited a growth rate of $5 \%$ over the last decade. During this period, the expansion of private sector has impacted the employment and energy consumption. Since then the more is the employment the more is the energy use. This causality is found for RDC and Egypt.

Table 1a - Granger causality tests from Employment to energy use over the period 1991-2010, bivariate (ENERGY, EMPLOYMENT) model

\begin{tabular}{|c|c|c|c|c|c|}
\hline & \multirow{2}{*}{$\begin{array}{l}\text { Estimated } \\
\text { coefficient }\end{array}$} & \multirow[t]{2}{*}{ Test Statistic } & \multicolumn{3}{|c|}{ Bootstrap critical values } \\
\hline & & & $1 \%$ & $5 \%$ & $10 \%$ \\
\hline Algeria & 13.6179 & $4.6194 *$ & 12.1608 & 7.1353 & 3.6266 \\
\hline Benin & 32.2470 & $3.5041 *$ & 15.5194 & 9.7035 & 3.0873 \\
\hline Cameroon & -8.1003 & $-5.6140 * *$ & 10.9978 & 5.3617 & 2.9579 \\
\hline Democratic Republic of Congo & 15.9627 & 1.3787 & 16.3313 & 11.9808 & 6.0135 \\
\hline Egypt & -14.8695 & -2.8888 & 14.2093 & 8.0990 & 3.7075 \\
\hline Ethiopia & 7.4936 & $5.6224 * *$ & 12.6206 & 5.5114 & 3.7970 \\
\hline Ghana & 1.7356 & 1.1984 & 28.8942 & 23.2109 & 18.6550 \\
\hline Kenya & -0.8908 & $-2.9158 *$ & 18.5234 & 7.2404 & 2.1498 \\
\hline Morocco & 0.8588 & .48290 & 23.8906 & 16.1617 & 10.4611 \\
\hline Mozambique & 5.0644 & $4.8598 * *$ & 16.2465 & 7.3354 & 3.6098 \\
\hline Nigeria & -3.6854 & -1.0634 & 10.6222 & 8.8407 & 7.4644 \\
\hline Senegal & 7.0213 & 1.0686 & 13.3082 & 10.2569 & 8.1749 \\
\hline
\end{tabular}

\footnotetext{
${ }^{15}$ Details for full estimations including control variables (economic growth, inflation and exchange terms) are similar to those reported in the paper and available upon request from authors.
} 


\begin{tabular}{lrrrrr} 
South Africa & 36.7667 & 2.1850 & 20.3577 & 13.8808 & 9.1480 \\
Tanzania & -7.6994 & $-6.8572^{* *}$ & 16.8978 & 6.1462 & 4.0709 \\
Tunisia & -50.1022 & $-3.0346^{*}$ & 17.5763 & 6.9569 & 2.3647 \\
Zambia & -2.6069 & $-3.5469^{*}$ & 13.4334 & 8.8309 & 3.0019 \\
\hline \hline & $* * * . * * . *$ : significance at the 1\%. 5\% and 10\% levels. respectively. \\
$\mathrm{H}_{0}$ : EMPLOYMENT does not cause ENERGY.
\end{tabular}

Table $1 \mathrm{~b}$ - Granger causality tests from energy use to Employment over the period 1991-2010, bivariate (ENERGY, EMPLOYMENT) model

\begin{tabular}{|c|c|c|c|c|c|}
\hline & \multirow{2}{*}{$\begin{array}{l}\text { Estimated } \\
\text { coefficient }\end{array}$} & \multirow[t]{2}{*}{ Test Statistic } & \multicolumn{3}{|c|}{ Bootstrap critical values } \\
\hline & & & $1 \%$ & $5 \%$ & $10 \%$ \\
\hline Algeria & 0.0097 & $3.1937^{*}$ & 5.4087 & 3.8520 & 2.6402 \\
\hline Benin & 0.0021 & $3.1242 *$ & 6.1128 & 4.0525 & 2.6952 \\
\hline Cameroon & -0.0033 & -.6694 & 17.1437 & 13.2661 & 10.3358 \\
\hline Democratic Republic of Congo & -0.0042 & $-9.3301 * *$ & 10.556 & 7.227 & 5.869 \\
\hline Egypt & 0.0045 & $5.0459 * *$ & 7.4396 & 4.8455 & 3.7854 \\
\hline Ethiopia & -0.0033 & -1.6332 & 22.4027 & 17.5379 & 13.9390 \\
\hline Ghana & 0.0044 & .95624 & 2.4674 & 1.9387 & 1.5434 \\
\hline Kenya & 0.0239 & $18.152 * * *$ & 16.6476 & 9.8366 & 5.9083 \\
\hline Morocco & -0.0054 & -3.7382 & 15.3198 & 12.4198 & 10.2056 \\
\hline Mozambique & -0.0099 & $-6.5583 * *$ & 8.526 & 5.558 & 3.164 \\
\hline Nigeria & -0.0003 & -.15636 & 12.7217 & 8.4359 & 4.5019 \\
\hline Senegal & 0.0009 & 2.2919 & 7.4951 & 6.1200 & 5.1631 \\
\hline South Africa & -0.0005 & -.46596 & 9.9933 & 4.5940 & 2.5719 \\
\hline Tanzania & 0.0085 & $4.2042 *$ & 14.036 & 6.629 & 3.387 \\
\hline Tunisia & -0.0002 & -.47408 & 11.854 & 5.309 & 3.4448 \\
\hline Zambia & -0.0087 & -.88832 & 21.4341 & 12.6276 & 6.4907 \\
\hline
\end{tabular}

For the second group of countries, the causality is running from energy use to employment. Zambia's economy has grown at an average of 5 percent per annum over the past decade, and this has leads to an increased demand for energy too. Demand for electricity has grown at an average of about 3 percent per annum largely due to the increased economic activity in the country, particularly in the agriculture, manufacturing, and mining sectors. With increased economic growth come higher rates of employment. As the population gains greater access to employment, their capacity to use energy also increases. Furthermore, the rural-urban drift continues, with employment being the main pull factor. And as the urban population swells, so does energy use. More often than not, these people could not afford electricity and other types of energy when they were in rural areas, but once they move to the city and find employment, they gain the extra capacity for energy consumption.

DRC and Mozambique show a negative and significant impact of energy use on employment. DRC is a Fragile State and was in a civil war. Mozambique before 2010 
was one of the poorest countries in Africa. Recently substantial energy resources were found. In the two considered countries, most of the population use biomass as the main source of energy. This implies that people are involved in the activities of collecting woods and other energy sources. These activities are not considered as productive activities and are informal activities. One must note that Africa has the highest rate of biomass energy in its energy mix (different sources of energy that it uses). While in some countries this activity is becoming more organized and more linked to employment. Some people are creating enterprises specialized in this field. They are recruiting people in order to collect these energy materials and they are selling it in formal and informal markets. Since then, the energy use of biomass is creating employment directly and indirectly. But this phenomenon is not observed in all countries. One can guess that in Mozambique and DRC this is not the case yet.

\section{Policy discussion and implications}

Africa shows strong diversity of situations and causality between energy use and employment. For the first group of countries (Cameroon, Ethiopia, Tunisia and Zambia), the revenue effect is overwhelming all the other effects. So, resolving first the issue of employment will impact positively the use of energy which itself will boost employment and so forth. As far as the second group is concerned, the demand side will play the most important role in boosting employment. In this case, investment in the energy sector will be the key factor in the policy to be implemented to boost employment. The third group of countries (Algeria, Benin, Kenya and Tanzania) could use the two effects of revenue and demand as leverage because the two effects have the same positive impact on employment and energy use. For the D.R. Congo and Mozambique, restructuring and formalizing the energy sector by shifting the energy use from the informal sector to more organized one, could be the main source of employment creation in the future.

This analysis has also strong policies implications especially in matter of fiscal policies. As Africa is facing massive youth employment challenge and needs more sustainable growth, some voices are advocating for a change in the fiscal policies following the double-dividend hypothesis. Advocating a shift in the fiscal policies by taxing more energy and less employment does not cause necessarily the desired outcomes as advocated in most double-dividend literature. The revenue-neutral 
substitution of environmental taxes (energy taxes) for ordinary labour taxes might not offer the desired double dividend: (1) improve the environment but also (2) reduce the costs of labour and improve employment. Our causality tests show that this may work only in few countries. For big players and most populated countries these shifts may not happen.

Besides, subsidies to energy are widespread in Africa and several empirical papers suggest cutting such subsidies based on their total costs and their environmental harms. As employment is becoming a hot issue in African countries, such policies may be not desired since this policy may lower energy use and therefore employment. Subsidizing energy in order to increase the employment is not a valid option for all African countries.

The importance of energy use in employment generation should not overshadow the environmental consequences of heavy reliance on fossil fuel consumption. Africa needs to explore and use its potential of renewable energy in order to meet employment and energy provision challenges. The initiative taken by the $\mathrm{UN}$ in order to foster sustainable energies in sub-Saharan Africa (SE4ALL) can challenge both energy needs and employment challenge ${ }^{16}$.

Our paper shows that there is no unique and universal policy in matter of energy and employment to recommend in Africa. We need to have a deep understanding of each country in order to better assess the required policies.

\section{Conclusion}

In this study, we implemented a bootstrap panel analysis of causality between energy use and employment for a sample of 16 African countries, which allows for crosscountry dependence, without requiring the use of pre-tests for a unit root. Our paper shows diverse causalities between employment and energy use. While there is a strong link in most countries, our estimates did not indicate any causality in big African players like South Africa, Nigeria, Morocco, Ghana and Senegal. Specifically, we found empirical evidence of a unidirectional Granger causality from employment to energy use in Cameroon, Ethiopia, Tunisia, Zambia, of a

\footnotetext{
${ }^{16}$ Sustainable energy for All (SE4ALL) is a global initiative launched in 2011 by the UN Secretary General Ban Ki-Moon. It aims to catalyze major new investments in the energy sector to achieve three objectives: ensuring universal access to modern energy services, doubling the global rate of improvement in energy efficiency, and doubling the share of renewable energy in the global energy mix. Some 80 governments from around the world have formally engaged with the initiative including 42 countries in the Sub-Saharan Africa.
} 
unidirectional Granger causality from energy use to employment in DRC and Egypt, and of a bidirectional Granger causality for Algeria, Benin, Kenya, Mozambique and Tanzania. Besides, our investigation indicates that there is no general trend in Africa in matter of energy and employment. Indeed, each country is a special case needing specific employment and energy policies. 


\section{References}

Akarca A.T. and T.V. Long (1979), Energy and employment: a time-series analysis of the causal relationship. Resources and Energy, Volume 2, Issues 2-3, OctoberNovember 1979, Pages 151-162.

Andersen T.B. and Dalgaard C-J. (2013), Power outages and economic growth in Africa, Energy Economics 38 (2013) 19-23.

Arouri, M.H., Ben Youssef, A., Mhenni, H and Rault, C. 2014. Energy use and Economic Growth in Africa: A Granger Causality Panel investigation. Economics Bulletin, Vol 34, $\mathrm{N}^{\circ} 2,1247-1258$.

Barsky, Robert B. and Kilian L. (2004), Oil and The Macroeconomy Since The 1970s. Journal of Economic Perspectives, 2004, v18 (4, Fall), 115-134.

Blazejczack, J., Braun, F.G., and Edler, D., Schill, W-P. 2011. Economic effects of Renewable energy expansion: A Model-Based Analysis for Germany. DIW Berlin Discussion Papers $N^{\circ} 1156$.

Bloom, D., Humair, S., Rosenberg, L., Sevilla, J.P., \& Trussell, J. 2014. Capturing a Demographic Dividend: Source, Magnitude and Realization, in "One Billion People, One Billion Opportunities" Soucat, A., and Mthuli, N. (ed.) (Chapter 2), African Development Bank. Tunis. P. 23-39.

Böhringer, C., Keller, A., and van der Werf, E. (2013). Are green hopes too rosy? Employment and welfare impacts of renewable energy promotion, Energy Economics $36,277-285$.

Bovemberg, A.L. and Goulder L.H (2001), Environmental Taxation and Regulation, BNER Working Paper Nº458, September 2001.

Breusch, T., and Pagan, A. (1980). The Lagrange multiplier test and its applications to model specification in econometrics. The Review of Economic Studies, 47(1):

239.253 .

Cameron, L. and van der Zwaan, B., (2012). Employment in renewables: a literature review, mimeo.

Çetin M., and Eğrican N. (2011), Employment impacts of solar energy in Turkey. Energy Policy, Volume 39, Issue 11, November 2011, Pages 7184-7190.

Chang T, Fang W., and Wen Li-Fang (2001), Energy consumption, employment, output, and temporal causality: evidence from Taiwan based on cointegration and error-correction modelling techniques, Applied Economics, Volume 33, Issue 8, 2001.

Cheng B. S. (1998), Energy consumption, employment and causality in Japan: a multivariate approach. Indian Economic Review, 1998. Vol. XXXIII, pp. 19-29.

Eberhard, A. (2013). Africa's Power Crisis. CBC Africa Infrastructure Investment Report. Pp 81-87. 
Erol U. (1990) Spectral analysis of the relationship between energy consumption, employment, and business cycles. Resources and Energy, Volume 11, Issue 4, March 1990, Pages 395-412

Frondel, M., Ritter, N., Schmidt, C. and Vance, C. (2009). Economic Impacts from the promotion of renewable energy technologies: the German experience. Energy Policy 38, 4048-4056.

Ghosh S. (2009), Electricity supply, employment and real GDP in India: evidence from cointegration and Granger-causality tests. Energy Policy, Volume 37, Issue 8, August 2009, Pages 2926-2929

Goulder L.H. (1994), Environmental Taxation and the "Double Dividend": A Reader's Guide, NBER, Working Paper, n²4896.

Heavner, B., and Churchill, S. (2002). Renewable work. Job growth from renewable energy development in California. Los Angeles: CALPRG Charitable Trust; 2002.

Herrero, S. T., Ürge-Vorsatz, D., Arena, D., Telegdy, A. 2011. Co-benefits quantified: employment, energy security and fuel poverty implications of the large-scale, deep retrofitting of the Hungarian building stock, ECEEE Summer Study, Energy Efficiency first: the foundation of a low carbon society. 1213-1224.

Hillebrand, B., Buttermann, H.G., Behringer, J.M., Bleuel, M. (2006). The expansion of renewable energies and employment effects in Germany. Energy Policy, 34, 34843494.

Jeeninga, H.; Weber, C.; Mäenpää, ; Rivero García, F.; Viltshire, V. and Wade, J. (1999), Employment impacts of energy conservation schemes in the residential sector: calculation of direct and indirect employment effects using a dedicated input/output simulation approach. ECN Policy Studies. 1-10-1999

Jespersen J. (1999), Reconciling environment and employment by switching from goods to services? A review of Danish experience. European Environment, Volume 9, Issue 1, pages 17-23, January/February 1999

Kónya, L. (2006), Exports and growth: Granger causality analysis on OECD countries with a panel data approach. Economic Modelling, 23, 978-982.

Laitner S., Bernow S., and DeCicco J. (1998), "Employment and other macroeconomic benefits of an innovation-led climate strategy for the United States". Energy Policy, Volume 26, Issue 5, April 1998, Pages 425-432.

Lambert R. J., Pereira S. P. (2012), The challenges of determining the employment effects of renewable energy. Renewable and Sustainable Energy Reviews, Volume 16, Issue 7, September 2012, Pages 4667-4674.

Lehr, U., Lutz, C., and Edler, D. (2012). Green Jobs? Economic impacts of renewable energy in Germany, Energy Policy, 47, 358-364. 
L'Horty, Y., and Rault C. (2004), "Inflation, Minimum Wage and Other Wages: An Econometric Study of French Macroeconomic Data", Applied Economics 36 (4), 277 290.

L'Horty Y. and Rault C. (2003), "Why Is French Equilibrium Unemployment So High? An Estimation of the WS-PS Model", Journal of Applied Economics 6 (1).

Llera, E., Scarpellini, S., Aranda, A., and Zabalza, I. (2013). Renewable and Sustainable energy Reviews, 262-271.

Murry, D.A. and Dan, G.D. (1992), "The energy consumption and employment relationship: A clarification". Journal of Energy and Development; (United States); 1992, Volume: 16:1

Narayan P. K. (2005), Electricity consumption, employment and real income in Australia evidence from multivariate Granger causality tests. Energy Policy, Volume 33, Issue 9, June 2005, P. 1109-1116

Openshaw K. (2010), Biomass energy: Employment generation and its contribution to poverty alleviation. Biomass and Bioenergy, Volume 34, Issue 3, March 2010, Pages 365-378.

Papapetrou E. (2001), Oil price shocks, stock market, economic activity and employment in Greece. Energy Economics. Volume 23, Issue 5, September 2001, Pages 511-532

Payne J.E. (2009), On the Dynamics of Energy Consumption and Employment in Illinois, The Journal of Regional Analysis and Policy, 39(2): 126-130.

Phillips, P.C.B. (1995), Fully Modified Least Squares and Vector Autoregression, Econometrica, vol 63, 5, pp 1023-1078.

Rutovitz, J., and Atherton, A. 2009, Energy sector jobs to 2030: a global analysis. Prepared for Greenpeace International by the Institute for Sustainable Futures, University of Technology, Sydney.

Schneider K. (1997), Involontary Unemployment and Environmental Policy: The Double Dividend Hypothesis , Scandinavian Journal of Economics, 99, n ${ }^{\circ}$, p. 4559.

Shi X., Heerink N., and Qu F. (2009), The role of off-farm employment in the rural energy consumption transition: A village-level analysis in Jiangxi Province, China Economic Review, Volume 20, Issue 2, June 2009, P. 350-359.

Simas, M., and Paca, S. 2014. Assessing employment in rewable energy technologies: A case study for wind power in Brazil.

Singh, V., and Fehrs, J. (2001). The work that goes to renewable energy. Washington, DC. Renewable Energy Policy Project, REPP Research Report N¹3: 2001. 
Smith S. (1992), Taxation and the Environment: A Survey, Fiscal Studies, 13, p. 2157.

Soucat, A. \& Mthuli, N. (2014), "One billion opportunities: The changing landscape of human capital in Africa", in "One Billion People, One Billion Opportunities" Soucat, A., and Mthuli, N. (ed.) (Chapter 1), African Development Bank. Tunis. P. 122.

Stenehjem, E.J.; Metzger, J.E. (1976), "Framework for projecting employment and population changes accompanying energy development". Technical Report. Argonne National Lab., IL (USA)

Tourkolias, C., and Misrasgedis, S. (2011). Quantification and monetization of employment benefits associated with renewable energy technologies in Greece, Renewable and Sustainable Energy Reviews 15, 2876-2886.

Vines, A. (2013). Africa's expanding energy landscape. CBC Africa Infrastructure Investment Report. Pp 92-101.

Wei M., Patadia S., and Kammen D. M. (2010), Putting renewables and energy efficiency to work: How many jobs can the clean energy industry generate in the US?. Energy Policy, Volume 38, Issue 2, February 2010, Pages 919-931

World Bank, 2013. World Development Indicators 2013. World Bank. Washington.

World Economic Forum (2012), Energy for Economic Growth. Industry Agenda. Energy vision 2012 update. Prepared in partnership with IHS CERA.

Yu E.S.H., Jin J. C. (1992), Cointegration tests of energy consumption, income, and employment. Resources and Energy, Volume 14, Issue 3, September 1992, Pages 259-266

Yu E.S.H, Chow P.C.Y, Choi J.Y. (1988), The relationship between energy and employment: a re-examination. Energy System Policy 1988;11:287-95.

Yu E.S.H, Lee, A. R (1995), Relationship between US energy consumption and employment: Further evidence. - Energy sources, Volume 17, Issue 5, 1995.

van der Zwaan, B., Cameron, L. and Kober, T. (2013). Potential for renewable energy jobs in the Middle East, Energy Policy, 60, 296-304. 